\title{
Fight against terror 'needs science institute'
}

Erika Check, Washington

The US National Academy of Sciences has called on the government to create a new institute for homeland security to assist policy-makers in the fight against terrorism.

The academy also asks for the creation of a new granting arm of the National Institutes of Health to fund high-risk research, along the lines pioneered by the Defense Advanced Research Projects Agency (DARPA).

The requests are made in a report that the academy, together with the National Academy of Engineering and the Institute of Medicine, has been painstakingly preparing since shortly after the terrorist attacks of 11 September last year. The report, which was released on 24 June, also recommends a wide range of scientific measures to defend the country from nuclear, biological, chemical, computer and infrastructure attacks.

The institute would, the report says, function as a contractor to the government, and would help to test and set standards for devices to prevent and contain terrorist attacks. These include sensors that would help emergency workers, food and shipping inspectors and city officials to thwart biological, chemical and nuclear attacks.

"There is going to be a proliferation of technologies and it will be important to characterize how they work and how they can best be deployed," says Richard Klausner, a former director of the National Cancer Institute and co-chair of the panel that wrote the report, who now works for the Bill and Melinda Gates Foundation in Seattle, Washington.

As well as the new granting mechanism at the NIH, the report suggests that the Department of Agriculture should support a new funding programme to coordinate the nation's response to plant pathogens. It also calls for the United States to take extra steps to recruit and train the next generation of scientists and engineers.

The report adds that the government should do more to track nuclear weapons and other radioactive materials, and to provide more funding to help Russia dilute its supply of highly enriched uranium. And it calls for more research in many areas, including the psychological response to terrorism, the human immune system, and the ability of contaminants to permeate the water supply.

The report does not suggest a budget for any of these initiatives. And as it was not requested by the government, some have questioned its likely impact. But Congress seems to be receptive to the report, and committees in both the House and the Senate have arranged hearings on its findings.
Some researchers complained that the document was silent on issues such as how to deal with the publication of what it calls "sensitive but unclassified" research. The report says that the White House Office of Science and Technology Policy should begin dialogue with scientists on this issue, but does not recommend any particular approach to it.

Critics also argue that the report misses the opportunity to urge better integration of science into US intelligence agencies, which have been criticized for their failure to prevent last September's attacks.

Much of the report was drafted before 6 June, when President George W. Bush introduced plans to create a new Department of Homeland Security. But researchers hope that it will help to set the scientific agenda for the department, which Bush promised would coordinate research against terrorist threats.

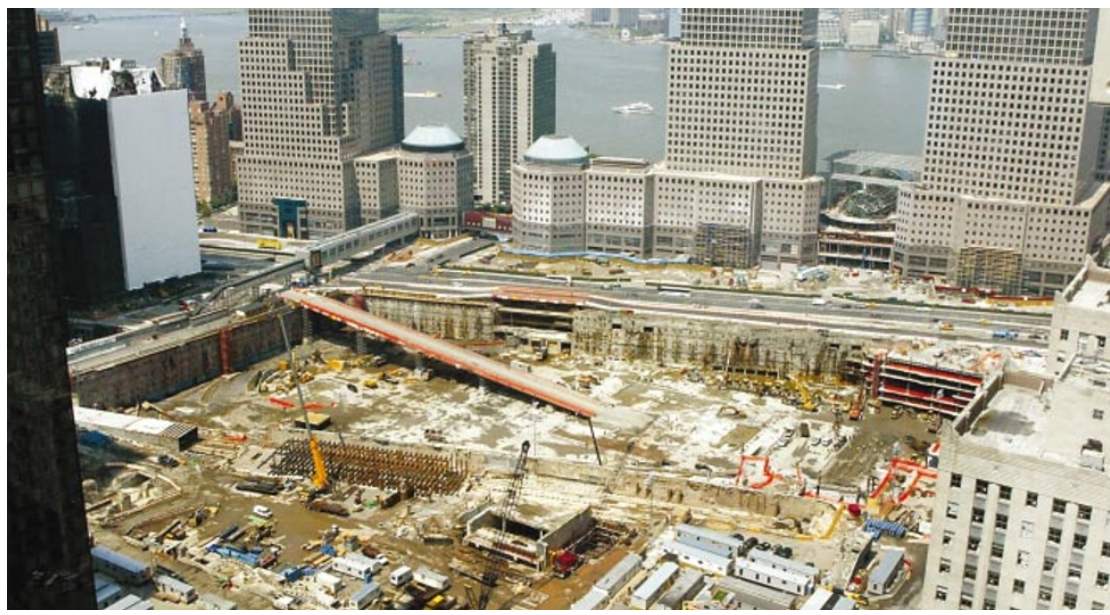

Prominent US scientists have called for research to help prevent a repeat of 11 September's attacks.

\section{Lack of funds puts 'bubble fusion' replication on hold}

\section{Geoff Brumfiel, Washington}

Efforts to replicate an experiment that detected 'bubble fusion' in a small jar are struggling to win funds, prolonging a controversy over the validity of the result.

When the original experiment was published in March (Science 295, 1868-1873; 2002), it sparked a keen debate over whether nuclear fusion had actually occurred. A team led by Rusi Taleyarkhan, a nuclear engineer at Oak Ridge National Laboratory in Tennessee, claimed success based on measurements of two major by-products of fusion, neutrons and tritium.

But critics said that an internal review at Oak Ridge six months earlier had called those measurements into question. Recalling the discredited 'cold fusion' experiments a decade earlier, researchers asked for an independent effort to replicate the results.

Lee Reidinger, deputy director of Oak

Ridge, convened a multidisciplinary team, including Taleyarkhan, to refine the original set-up and use better detectors. The effort was expected to cost up to $\$ 500,000$.

Reidinger says he hoped to use part of Oak Ridge's budget that is reserved for research conducted at the laboratory's own discretion. But he says that officials at the Department of Energy told him this could only be used for original experiments, not for verifying existing work. Now the group is to submit a formal proposal for funding - a process that will take several more months, with uncertain prospects of success.

Taleyarkhan, meanwhile, has won a new grant from the Defense Advanced Research Projects Agency (DARPA), believed to be worth around $\$ 250,000$, to continue his own investigation. The funding from DARPA, which specializes in high-risk projects, will be used to scale up his apparatus. Taleyarkhan will be looking at the process's potential not just for fusion power, but also for "more immediate applications" as a neutron source, perhaps for radiography or detection of explosives.

$\mathrm{He}$ also says he is helping several groups worldwide to reproduce his original result, although he declined to identify them for fear that publicity could adversely affect their funding proposals. "I believe it will take at least four to six months before you start seeing results," he adds. 